\title{
BAHASA: KUNCI SUKSES KOMUNIKASI KATEKIS DI ZAMAN MILENIAL
}

\author{
Oleh: Sabinus Frando R. Soi
}

\begin{abstract}
Abstrak:
Menjadi katekis di zaman milenial memiliki tantangan yang beragam. Pilihan untuk menjadi katekis adalah sebuah panggilan untuk melayani. Seiring dengan itu panggilan menjadi katekis disertai dengan tantangan yang bisa saja menjadi problem tersendiri dalam perwujudannya. Katekis telah ditantang oleh arus modernisasi yang di dalamnya terkandung individualisme, hedonisme, sekularisme bahkan radikalisme yang menuntut katekis selektif dalam bersosialisasi. Dalam rangka sosialisasi dengan masyarakat (baca: umat Allah) itulah katekis membutuhkan bahasa yang merupakan alat komunikasi utama manusia. Apakah bahasa digunakan secara baik dan benar dalam memberikan pengajaran dan pewartaan Kerajaan Allah kepada umat yang adalah fokus dan lokus pelayanan seorang katekis? Tulisan ini bertujuan untuk memberikan gambaran yang lebih rinci tentang penggunaan bahasa oleh katekis, sebagai media pewartaan kerajaan Allah di zaman milenial.
\end{abstract}

Kata Kunci: Bahasa, Komunikasi, Katekis.

\section{Pendahuluan}

$\mathrm{B}$ ahasa sebagai sebuah kunci sukses komunikasi katekis di zaman milenial adalah sebuah tema yang digagas atas dasar pengamatan penulis. Dalam beberapa hal, katekis perlu dibekali dengan pengajaran bahasa yang baik. Meskipun pengajaran bahasa hanyalah sebuah mata kuliah dasar bagi seorang katekis kala menempuh pendidikan tetapi perlu diingat bahwa katekis tidak bisa melakukan pengajaran iman yang baik tanpa memiliki kemampuan yang baik dalam berbahasa. Tanpa bahasa, kegiatan komunikasi verbal tidak bisa berjalan secara efektif. Berkomunikasi berarti berinteraksi dengan sebuah komunitas/lingkungan kebahasaan.

\section{Bahasa: Kunci Sukses Komunikasi Manusia}

Secara etimologis bahasa berasal dari bahasa Sanskerta yaitu bhāṣā yang berarti kemampuan yang dimiliki manusia untuk berkomunikasi dengan manusia lainnya menggunakan tanda, misalnya kata dan gerakan. Hal ini menunjukkan bahwa fungsi pertama dan utama bahasa adalah sebagai alat sosialisasi manusia dengan komunitasnya. Fungsi bahasa inilah yang menentukan apakah manusia mampu bekerja sama dalam sebuah sistem sosial kemasyarakatan. Di pihak lain bahasa merupakan sebuah objek kajian linguistik dimana bahasa memiliki dua arti dasar yakni sebagai sebuah konsep abstrak, dan sebagai sebuah sistem linguistik yang spesifik. Bahasa Indonesia adalah contoh dari makna bahasa sebagai sebuah sistem linguistik yang spesifik. Ferdinand de Saussure, seorang linguis asal Swiss, adalah orang pertama yang merumuskan perbedaan kata dalam bahasa Perancis. Terdapat langage dalam arti bahasa sebagai sebuah konsep, langue dalam arti bahasa sebagai sistem linguistik yang spesifik, dan parole dalam arti bahasa sebagai penggunaan konkret bahasa tertentu sebagai tuturan. Berbicara mengenai bahasa sebagai konsep umum, dapat digunakan berbagai definisi yang menekankan aspek yang berbeda dari fenomena tersebut. Definisi tersebut juga memerlukan pendekatan dan pemahaman berbeda tentang bahasa, dan 
terkadang memberikan kajian teori linguistik yang berbeda atau bahkan bertentangan. ${ }^{1}$ Bahasa menjadi media pengungkapan diri dan pemahaman atas diri orang lain. Tanpa bahasa atau tanpa menggunakan bahasa yang baik dan benar, orang tidak mengalami perkembangan yang berarti. $^{2}$

Eksistensi bahasa hadir ketika bahasa digunakan dalam kehidupan sosial masyarakat untuk menyampaikan gagasan, berdiskusi, bercerita, ataupun memberikan ceramah dalam kegiatan-kegiatan kerohanian. Kesuksesan sebuah komunikasi terletak pada sejauh mana bahasa tersebut digunakan. Kualitas kesuksesan komunikasi ditentukan pula oleh kualitas penggunaan bahasa dalam menyampaikan ide, gagasan ataupun maksud kepada audiens (pendengar). Pengguna bahasa yang dimaksudkan dalam konteks ini adalah para katekis yang tugas pokoknya adalah memberikan pengajaran iman Katolik kepada umat. Seorang katekis yang berkualitas hendaknya memiliki kemampuan yang baik dalam berbahasa (menyampaikan maksud pembicaraan) kepada pendengarnya. Semakin baik bahasa yang digunakan oleh seorang katekis berarti semakin baik pula kualitas komunikasi yang terjadi. Dengan demikian, pemakaian bahasa dapat difungsikan dengan baik sebagai alat komunikasi utama dalam pola komunikasi manusia.

Selanjutnya akan muncul sebuah pertanyaan lain, bagaimana cara katekis agar memiliki kemampuan kebahasaan yang cukup agar karya pewartaan bisa terlaksana? Beberapa cara berikut ini coba penulis paparkan. Pertama, membaca. Bagi sebagian orang (Indonesia), ada anggapan bahwa membaca adalah kegiatan membuang waktu dan membosankan. Tesis ini berlaku karena masyarakat kita tidak terbiasa dengan membaca. Hasil penelitian Perpustakaan Nasional tahun 2017 menunjukan rata-rata orang Indonesia hanya mampu membaca buku 3-4 kali per minggu, dengan durasi waktu membaca per hari rata-rata 30-59 menit. Dan jumlah buku yang mampu dibaca sampai tuntas per tahun rata-rata hanya 5-9 buku. $^{3}$ Survei ini membuktikan bahwa secara umum minat baca masyarakat Indonesia sangat rendah. Membaca berarti mencari referensi, menemukan kalimat yang selanjutnya dapat dijadikan landasan untuk merangkai gagasan atau ide untuk dikomunikasikan kepada sesama. Membaca adalah kegiatan memahami makna yang terdapat dalam tulisan; dalam pengertian luas, membaca diartikan sebagai proses pengolahan bacaan secara kritis-kreatif yang dilakukan pembaca untuk memperoleh pemahaman menyeluruh tentang bacaan itu, yang diikuti oleh penilaian terhadap keadaan, nilai, fungsi, dan dampak bacaan itu. ${ }^{4}$ Dengan demikian, bagi seorang katekis membaca adalah kegiatan yang wajib dilakukan, tidak boleh tidak. Karena akan sangat berpengaruh terhadap karya pewartaan sabda Allah.

Kedua, menulis. Salah satu dari empat keterampilan berbahasa adalah menulis (berbicara, mendengar, menulis, dan membaca). Kegiatan menulis bukanlah sesuatu yang mudah. Kebiasaan menulis merupakan kegiatan turunan setelah membaca. Sebuah tulisan yang baik dihasilkan jika seseorang rajin membaca. Menulis dapat pula diartikan sebagai hasil kritik dari sebuah buku. Maka, katekis penting dibekali dengan teknik dasar penulisan agar dapat menyampaikan gagasan dalam bentuk tulisan. Sehingga media pewartaan tidak hanya melalui ceramah, kotbah yang bagus tetapi dapat disampaikan melalui sebuah tulisan yang bagus. Ketiga, diskusi. Diskusi diartikan sebagai sebuah pertemuan ilmiah untuk

\footnotetext{
${ }^{1}$ https://id.wikipedia.org/wiki/Bahasa\#Alat komunikasi, diakses tanggal 15 Desember 2018.

2 Yoseph Aryanto Ludoni, B.Sc., dalam Seminar Nasional di STKIP Citra Bakti Ngada. Flores Pos 05 November 2018

${ }^{3}$ https://nasional.kompas.com diakses tanggal 01 November 2018.

${ }^{4}$ Nurhadi, Teknik Membaca (Malang: Penerbit A3 ;Asah Asih Asuh, 2009), hlm. 2.
} 
bertukar pikiran mengenai suatu masalah. ${ }^{5}$ Kegiatan diskusi dapat dilakukan setelah melewati proses membaca. Setiap katekis memiliki gagasan yang berbeda-beda terhadap sebuah topik pembicaraan. Maksud dari kegiatan diskusi adalah gagasan atau ide yang dimiliki dapat dibagikan dalam sebuah forum pembicaraan sehingga informasi, pengetahuan yang diperoleh semakin bervariasi. Adanya diskusi juga bertujuan untuk mengurangi distorsi dalam karya pewartaan Sabda Allah. Semakin sering seorang katekis bertukar pikiran dalam sebuah forum diskusi maka perbendaharaan kata ataupun kalimat semakin bertambah. Hal ini sangat membantu katekis agar mampu menyampaikan gagasan (kotbah) menggunakan bahasa yang matang; selain itu, bahasa yang digunakan katekis dalam karyanya tidak terkesan monoton.

Tiga kegiatan di atas (membaca, menulis, diskusi) merupakan dasar atas suksesnya komunikasi (baca:pewartaan) Sabda Allah. Pendekatan-pendekatan ini perlu dipakai seorang katekis agar pewartaan tidak terpaku pada salah satu media saja tetapi dapat dilakukan dengan berbagai cara ataupun media. Ketiga hal ini juga yang mampu meningkatkan kompetensi (what you can do, kecekatan (how agile you are), dan perilaku (your attitude, your gesture $)^{6}$ dalam berkomunikasi.

\section{Komunikasi Milenial}

Komunikasi merupakan pengiriman dan penerimaan pesan atau berita antara dua orang atau lebih sehingga pesan yang dimaksud dapat dipahami. ${ }^{7}$ Dalam kegiatan komunikasi, kata-kata dijalin-satukan dalam suatu konstruksi yang lebih besar berdasarkan kaidah-kaidah sintaksis yang ada dalam suatu bahasa. Yang paling penting dari rangkaian kata-kata adalah pengertian yang tersirat di balik kata yang digunakan itu. Setiap anggota masyarakat yang terlibat dalam kegiatan komunikasi, selalu berusaha agar orang-orang lain dapat memahaminya dan di samping itu ia harus memahami orang lain. Dengan cara ini terjalinlah komunikasi dua arah yang baik dan harmonis. ${ }^{8}$ Lebih jauh Gorys Keraf menyatakan bahwa masyarakat kontemporer tidak akan berjalan tanpa komunikasi yang memiliki beberapa persyaratan seperti menguasai sejumlah besar kosa kata (perbendaharaan kata) yang dimiliki masyarakat bahasanya, serta mampu pula menggerakkan kekayaannya itu menjadi jaringan-jaringan kalimat yang jelas dan efektif, sesuai dengan kaidah-kaidah sintaksis yang berlaku, untuk menyampaikan rangkaian pikiran dan perasaannya kepada anggota-anggota masyarakat lainnya. ${ }^{9}$

Pola komunikasi di zaman milenial mengalami perkembangan yang sangat pesat dan cepat. Tingkat kepentingan komunikasi dewasa ini sudah luas dan kompleks sehingga membutuhkan kejelian/ketelitian dalam berkomunikasi. Perkembangan dan kemajuan teknologi yang sangat cepat juga mempengaruhi pola komunikasi manusia. Teknologi telah membantu manusia dalam perilaku komunikasi. Tetapi dalam beberapa hal kemajuan iptek menghilangkan esensi komunikasi; misalnya terjadi pergeseran fungsi bahasa tidak hanya sebagai alat penyampai pesan melainkan digunakan untuk menyebarkan fitnah, cemoohan, kebencian dan tindakan kriminal lainnya. Nah, sampai pada titik ini apakah katekis masih memiliki kemampuan untuk menyaring informasi untuk diwartakan kepada umat?

Kehidupan manusia di zaman modern mengalami banyak sekali perubahan. Perubahan pola komunikasi disebabkan oleh perubahan arus zaman yang digempur oleh berbagai macam perkembangan teknologi. Zaman dahulu manusia mengandalkan surat,

\footnotetext{
${ }^{5}$ Kamus Besar Bahasa Indonesia Edisi Keempat (Jakarta: Penerbit Gramedia, 2008), hlm. 334.

${ }^{6}$ Rheinald, Kasali, Self Driving (Jakarta: Penerbit Mizan, 2015), hlm. 6.

${ }^{7}$ Kamus Besar Bahasa Indonesia Edisi Keempat (Jakarta: Penerbit Gramedia, 2008), hlm. 721.

${ }^{8}$ Gorys, Keraf, Diksi dan Gaya Bahasa (Jakarta: Gramedia, 1984), hlm. 21.

${ }^{9}$ Ibid., hlm. 23
} 
telegram, radio, dan televisi sebagai media untuk menyampaikan berita atau pesan. Namun berbeda dengan sekarang ini. Informasi seolah berada di ujung jari. Manusia hanya membutuhkan handphone untuk menyampaikan informasi melalui aplikasi pesan singkat seperti sms, whatsApp, Messenger, Line, Signal, dan lain sebagainya. Ketika semua hal dapat dijangkau hanya melalui media yang disebutkan di atas maka akan terjadi efek lanjutan yaitu pola komunikasi manusia tidak dilakukan face to face (secara langsung) sehingga berimbas pada kurang pedulinya manusia terhadap situasi dan kondisi sosial kemasyarakatan. Tingkat kepercayaan manusia terhadap apa yang terdapat dalam media sosial (isu, berita, tulisan) lebih tinggi daripada apa yang terjadi dalam kehidupan nyata. Maka tidaklah heran seringkali terjadi jurang pemisah informasi antara yang ada dalam teknologi (virtual) dengan kenyataan.

Milenial (Generasi Y) adalah kelompok demografi yang lahir dalam rentang waktu awal 1980-an sampai awal tahun 2000-an. Disebut pula Echo Boomers karena adanya 'booming' (peningkatan besar) tingkat kelahiran pada tahun 1980-an dan 1990-an. Kaum milenial ditandai dengan sebuah karakter khusus yakni ditandai dengan penggunaan dan keakraban dengan komunikasi, media dan teknologi digital. ${ }^{10}$ Adanya keakraban dengan teknologi menimbulkan bergesernya pola komunikasi. Milenial tidak terbatas pada pola komunikasi konvensional melainkan sudah beralih pada media sosial. Ruang diskusi tidak terbatas pada tempat yang sempit, tetapi dapat dilakukan pada platform-platform digital melalui grup whatsApp, Facebook, Telegram. Komunikasi lebih fleksibel. Istilah generasi milenial sebenarnya diciptakan oleh dua pakar sejarah dan penulis Amerika, William Strauss dan Neil Howe.

\section{Katekis: 'oase' di tengah umat}

Paus Yohanes Paulus II dalam Ensiklik Redemptoris Missio menyatakan "katekis adalah saksi-saksi langsung dan pewarta-pewarta Injil yang tak tergantikan yang sebagaimana seringkali saya nyatakan dan alami dalam perjalanan-perjalanan misioner saya merupakan kekuatan basis persekutuan-persekutuan Kristen, teristimewa di dalam Gereja-Gereja Muda". ${ }^{11}$ Hal ini menjelaskan bahwa katekis memiliki peranan khusus dalam sebuah tugas pewartaan. Katekis adalah pengajar agama profesional di dalam Gereja Katolik. ${ }^{12}$ Katekis mendapatkan pendidikan formal dalam bidang kateketik, mencari nafkah di bidang katekese, mempunyai etika profesi sebagai pengajar agama, dan mengembangkan diri melalui suatu asosiasi katekis. Katekis bekerja sebagai guru agama di sekolah maupun di Paroki. ${ }^{13}$ Pada umumnya Katekis adalah lulusan dari Sekolah Guru Agama (SGA), atau Sekolah Pendidikan Guru (SPG) Agama, atau Akademi Kateketik, atau Sekolah Tinggi Kateketik (STKat) pada masa lalu, atau sekarang lulusan lembaga pendidikan tinggi yang mempunyai konsentrasi keilmuan di bidang agama Katolik dan metode mengajar dalam kurikulumnya. ${ }^{14}$ Kehadiran katekis di tengah umat ibarat oase di padang gurun. Katekis diharapkan memberikan pencerahan dan penyegaran iman kepada umat yang belum mendapatkan pengajaran iman yang baik. Dengan memberikan pengajaran iman yang baik sudah pasti menggunakan pola komunikasi yang baik pula. Pola komunikasi yang baik membutuhkan bahasa yang benar. Inteligensi seorang katekis dituntut agar mampu menyampaikan pesan dalam pengajaran iman sehingga tepat guna. Katekis sebagai pewarta Sabda Allah melakukan tindakan instrumental sebagai sarana untuk mencapai hasil tertentu melalui pola komunikasi yang

\footnotetext{
${ }^{10}$ Id.m.wikipedia.org, diakses tanggal 21 November 2018.

11 Frederikus Dhedhu, Katekis dan Lingkungan Hidup, dalam Jurnal Pastoral Atma Reksa Edisi Juli-

${ }^{12}$ Wikipedia Indonesia, https://id.wikipedia.org/wiki/Katekis, diakses tanggal 05 Agustus 2018.

${ }^{13}$ Wikipedia Indonesia, https://id.wikipedia.org/wiki/Katekis, diakses tanggal 05 Agustus 2018.

${ }^{14}$ Wikipedia Indonesia, https://id.wikipedia.org/wiki/Katekis, diakses tanggal 05 Agustus 2018.
} Desember 2016, hlm. 7-8. 
baik, benar dan tepat sasaran. Sebuah tujuan yang baik hendaklah dilakukan dengan cara yang baik pula agar karya pewartaan Sabda Allah melekat di hati umat sebagai subyek pewartaan tersebut. Katekis memberikan kesegaran kepada umat yang 'haus' akan Sabda Allah melalui media bahasa. Oleh karena tujuan yang sangat mulia inilah maka Katekis perlu dibekali dengan pengetahuan yang cukup agar katekis bisa menjadi 'oase' di tengah umat.

Katekis mengemban misi pastoral gereja sebagaimana terungkap dalam Yoh 20:21; Mat 28:18-20; Kis 1:8. ${ }^{15}$ Katekis diutus untuk mewartakan Kabar Baik, kabar keselamatan kepada semua umat dan menjadikan segala bangsa murid Kristus. Dengan misi ini, katekis mengemban tri tugas pastoral, yaitu: (a) Sebagai Nabi, mewartakan Injil kepada segala bangsa/mengajar; (b) Sebagai Imam, menguduskan; katekis memberikan teladan dalam kehidupan iman seperti hidup doa, ekaristi, dan karya sosial; (c) Sebagai Gembala, membimbing/memimpin umat beriman. ${ }^{16}$ Ketiga tugas mulia ini sudah tentu sangat membutuhkan kemampuan berbahasa yang mumpuni. Karya pewartaan tidak bisa terlaksana dengan baik bila seorang katekis tidak mampu berkomunikasi atau menyampaikan pesan kepada umat. Dengan demikian peranan bahasa tidak hanya sebagai alat komunikasi dalam kehidupan umat saja tetapi menyimpan potensi kuasa untuk membentuk pola pikir dan keyakinan masyarakat yang mewujud dalam perilaku dan struktur kehidupan sehari-hari. ${ }^{17}$ Bagaimana membentuk pola pikir dan keyakinan umat apabila katekis tidak disiapkan dengan pemahaman kebahasaan yang benar? Bahasa sebagai sebuah dasar dari hasil karya manusia dapat membentuk mentalitas pemakai bahasa tersebut.

\section{Meneladani Gaya Bahasa Yesus}

Bahasa yang digunakan para katekis untuk mewartakan karya keselamatan Allah terungkap dalam sebuah gaya bahasa (style). Apakah gaya bahasa yang digunakan benarbenar menunjukkan jiwa seorang katekis? Style (stilus; Latin) merupakan kemampuan dan keahlian untuk menulis atau mempergunakan kata-kata secara indah. ${ }^{18}$ Persoalan gaya bahasa tidak hanya terletak pada pemakaian bahasa semata tetapi mencakup semua hirarki kebahasaan seperti pilihan kata secara individual, frasa, klausa, dan kalimat bahkan mencakup pula sebuah wacana secara keseluruhan. Bagaimana pula seorang katekis dapat mengungkapkan pikiran melalui bahasa yang khas yang memperlihatkan jiwa dan kepribadiannya? Keraf memaparkan tiga unsur penting untuk sebuah gaya bahasa yang baik yaitu kejujuran, sopan santun, dan menarik ${ }^{19}$.

Kejujuran dalam berbahasa berarti mengikuti kaidah yang baik dan benar dalam berbahasa. Dengan demikian pemakai bahasa (katekis) perlu menyampaikan isi pikirannya secara jujur, tidak berbelit tak menentu sehingga pendengar dapat dengan cepat menyerap inti pembicaraan (maksud) yang disampaikan. Kejujuran berbahasa mencakup pula kejelasan tujuan yang otentik, jujur, dan berdaya ubah.

Manifestasi sopan santun dalam berbahasa adalah kejelasan dan kesingkatan seperti yang tertuang dalam beberapa kaidah berikut ini: (1) kejelasan dalam struktur gramatikal dan kalimat; (2) kejelasan dalam korespondensi dengan fakta yang diungkapkan melalui kata-kata dan kalimat; (3) kejelasan dalam pengurutan ide secara logis; (4) kejelasan dalam penggunaan kiasan dan perbandingan. Katekis sebagai pewarta kabar baik tentu memiliki gaya bahasa yang sopan, teratur, tidak berbelit supaya tidak menimbulkan pertanyaan dari

\footnotetext{
${ }^{15}$ Bosco Da Cunha, Pastoral Liturgi (Malang: Dioma, 2003), hlm. 1-2.

${ }^{16}$ Ibid.

${ }^{17}$ Michel Foulcault, Diskursus Tentang Bahasa (Jakarta: Gramedia, 1971), hlm. 78.

${ }^{18}$ Keraf, Gorys. Op.Cit., hlm. 112.

${ }^{19}$ Ibid., hlm. 113-115.
} 
umat sebagai subyek karya pewartaannya. Misalnya, ketika menyampaikan sebuah renungan singkat, bahasa yang digunakan hendaknya disesuaikan dengan lingkungan umatnya. Apakah renungan disampaikan di kampung atau di kota? Dua situasi ini harus disesuaikan dengan pemakaian bahasa yang senada pula agar tidak timbul pertanyaan dari para pendengar (umat).

Menarik. Ukuran yang dipakai dalam menentukan menarik atau tidaknya sebuah gaya bahasa tergantung pada beberapa unsur penting berikut ini, yaitu: variasi, humor yang sehat, pengertian yang baik, tenaga hidup (vitalitas), dan penuh khayal (imajinasi). Pemakaian bahasa yang variatif dan imajinatif menghadirkan kekuatan bahasa dalam memberikan energi berdaya ubah terhadap pendengar.

Katekis, sebagai pewarta karya keselamatan Allah patut memperhatikan tiga hal yang dipaparkan di atas. Gaya bahasa yang jujur, penuh sopan santun, dan menarik sejatinya memanifestasikan jati diri katekis sendiri. Perlu diingat bahwa Yesus dalam menjalankan karya keselamatan di dunia sering menggunakan perumpamaan. Tujuan Yesus sederhana agar pewartaan yang disampaikannya mudah dipahami dan dilaksanakan oleh setiap pendengarnya. Yesus tidak pernah memakai istilah rumit, yang sulit dipahami melainkan dengan perumpamaan-perumpamaan. Misalnya dalam Matius 21:33-46, Markus 12:1-12, Lukas 20:9-19; Perumpamaan tentang penggarap-penggarap Kebun Anggur; Lukas 13:6-9; Pohon ara yang Tidak Berbuah. Gambaran Yesus dalam dua contoh perumpamaan ini membuktikan bahwa Yesus mengajar untuk memperjelas apa yang sedang terjadi dalam situasi nyata. Yesus mengambil contoh perumpamaan dari situasi yang dialami, dikenal oleh para pendengar dalam kehidupan sehari-hari. Selain itu, Yesus juga menggunakan perumpamaan dalam sebuah cerita sebagaimana tampak dalam Perumpamaan Anak yang Hilang (Bdk. Lukas 15:11-32).

Yesus adalah pencerita unik dengan gaya bahasa yang sederhana, tidak berbelit-belit dan to the point. Pemakaian perumpamaan dalam karya pewartaanNya hendak membuktikan bahwa Yesus sangat memahami situasi para pendengarNya. Dengan pola komunikasi seperti ini tidaklah mengherankan Yesus sangat dekat dengan setiap orang yang mendengarkan perkataan-Nya. Yesus tidak membutuhkan pencitraan agar Ia memiliki banyak pengikut. Sekali lagi, dengan pendekatan gaya bahasa (perumpamaan/analogi) Yesus menarik hati banyak orang untuk mendengarkan perkataan-Nya.

\section{Penutup}

Lantas, apa sajakah keuntungan seorang katekis ketika melakukan pengajaran iman sebagaimana Yesus lakukan? Pertama, katekis adalah guru iman. Seorang guru yang baik hendaklah mengajar dengan bahasa yang sederhana serta mudah dipahami para muridnya. Artinya pola komunikasi disesuaikan dengan latar belakang para pendengar. Kedua, tujuan pengajaran iman adalah untuk dilaksanakan oleh para pendengar. Nah, bagaimana mungkin seseorang dapat melaksanakan apa yang diajarkan bila ia tidak memahami maksud yang disampaikan si pengajar (guru)? Dua hal ini patut diperhatikan agar karya pewartaan Kerajaan Allah dapat diamalkan oleh pendengar (umat). Oleh karena itu, katekis harus menyesuaikan pilihan kata sesuai dengan lapisan pemakaian bahasa, Karena kata merefleksikan tingkah laku sosial dari orang-orang yang mempergunakannya. 


\section{Daftar Kepustakaan}

\section{Buku-buku}

Da Cunha, Bosco. 2003. Pastoral Liturgi. Yogyakarta, Penerbit Dioma.

Dhedhu, Frederikus, "Katekis dan Lingkungan Hidup", dalam Jurnal Pastoral Atma Reksa Edisi Juli-Desember 2016.

Foulcault, Michel. 1971. Diskursus Tentang Bahasa.

Kamus Besar Bahasa Indonesia Edisi Keempat. 2008. Jakarta: Penerbit Gramedia.

Kasali, Rheinald. 2015. Self Driving. Jakarta, Mizan.

Keraf, Gorys. 1984. Diksi dan Gaya Bahasa. Jakarta, Gramedia.

Nurhadi. 2009. Teknik Membaca. Malang: Penerbit A3 (Asah Asih Asuh).

Yoseph Aryanto Ludoni, B.Sc., dalam Seminar Nasional di STKIP Citra Bakti Ngada. Flores Pos 05 November 2018

\section{Internet}

id.m.wikipedia.org, diakses tanggal 21 November 2018.

https://nasional.kompas.com diakses tanggal 01 November 2018.

https://id.wikipedia.org/wiki/Bahasa\#Alat_komunikasi

Wikipedia Indonesia, https://id.wikipedia.org/wiki/Katekis, diakses tanggal 05 Agustus 2018. 